Waskito, H. • A. Nuraini · N. Rostini

\title{
Respon pertumbuhan dan hasil cabai keriting (Capsicum annuum L.) Ck5 akibat perlakuan pupuk NPK dan pupuk hayati
}

\section{Response of growth and yield of curly red pepper (Capsicum annuum L.) Ck5 due to NPK fertilizer and biofertilizer}

Diterima : 18 Juli 2018/Disetujui : 4 Agustus 2018 / Dipublikasikan : 7 Agustus 2018

CDepartment of Crop Science, Padjadjaran University

\begin{abstract}
This study aims to find out response of growth and yield of curly red chili plant $\mathrm{cv}$. CK5 as a result of NPK and organic fertilizer. The experiment was conducted in Sindanglaya Village, District Sukamantri, Ciamis Regency West Java Province, from August 2017 until January 2018. The experiment design used was Split Plot Design with 4 replications. The main plot was the dosage of NPK fertilizer consisting of two levels : 50\% and 100\% NPK, and the sub plot was concentration organic fertilizer consisting of three levels : $0 \%$; $0.5 \%$; and $1 \%$. The results showed that : the effect of NPK dosage interaction with concentration of biological fertilizer occurs only at plant height of 28 day after planting, the best treatment was 100\% NPK dosage with $0.5 \%$ biofertilizer concentration. NPK fertilizer and concentration of biological fertilizers independently affected the amount and weight of fruit. The best dosage of NPK in producing the amount and weight of fruit was $100 \%$ NPK, and the best concentration of biofertilizer was $0,5 \%$.
\end{abstract}

Keywords: Biofertilizer - Curly pepper CK5 . Growth $\cdot$ NPK fertilizer • Yield

Sari. Penelitian ini bertujuan untuk mengetahui respon pertumbuhan dan hasil tanaman cabai keriting CK5 terhadap dosis pupuk NPK dan pupuk hayati Percobaan dilaksanakan di Desa Sindanglaya, Kelurahan Cibereum, Kecamatan Sukamantri, Kabupaten Ciamis Provinsi Jawa

\footnotetext{
Dikomunikasikan oleh Syariful Mubarok

Waskito, H. ${ }^{1} \cdot$ A. Nuraini ${ }^{2}$ - Neni Rostini ${ }^{2}$

${ }^{1}$ Mahasiswa Program Pascasarjana, Fakultas Pertanian,

Universitas Padjadjaran

2 Departemen Budidaya Pertanian, Fakultas Pertanian,

Universitas Padjadjaran

Jl. Raya Bandung Sumedang Km. 21, Jatinangor, Indonesia,

korespondensi: heruwaskito1978@yahoo.com
}

Barat dari bulan Agustus 2017 sampai Januari 2018. Rancangan percobaan menggunakan Split Plot dengan 4 ulangan. Yang menjadi main plot adalah dosis pupuk NPK yang terdiri dari dari 2 taraf yaitu 50\% dan 100\% NPK, dan sub plot adalah konsentrasi pupuk hayati yang terdiri dari 3 taraf yaitu : $0 \% ; 0,5 \%$; dan $1 \%$. Hasil percobaan menunjukkan bahwa: pengaruh interaksi dosis NPK dengan konsentrasi pupuk hayati hanya terjadi pada tinggi tanaman umur $28 \mathrm{HST}$, perlakuan yang terbaik adalah dosis NPK $100 \%$ dengan konsentrasi pupuk hayati 0,5\%. Pupuk NPK dan konsentrasi pupuk hayati secara mandiri berpengaruh terhadap jumlah dan bobot buah. Dosis NPK yang terbaik dalam menghasilkan jumlah dan bobot buah adalah $100 \%$ NPK, dan konsentrasi pupuk hayati yang terbaik adalah $0,5 \%$.

Kata kunci: Cabai CK 5 - Pupuk hayati - Pupuk NPK · Pertumbuhan $\cdot$ Hasil

\section{Pendahuluan}

Cabai (Capsicum annuum L.) merupakan tumbuhan yang digolongkan ke dalam anggota genus Capsicum. Bagian dari tumbuhan cabai yang digunakan yaitu buahnya sebagai sayuran maupun bumbu sebagai penguat rasa makanan terutama sebagai bahan rasa pedas seperti sambal. Cabai ini merupakan tanaman semusim yang berdiri tegak, berbentuk perdu, dan menjadi salah satu komoditas sayuran yang banyak dibudidayakan, dan menjadi salah satu komoditas paling populer di dunia. Cabai memiliki sebutan yang berbeda-beda di beberapa daerah di Indonesia, seperti cabe (Sunda), lombok (Jawa), cabhi (Madura), campli (Aceh), lado (Minangkabau), tabia (Bali), rica 
(Manado), lada (Makasar), dan riksak (Papua Barat).

Sentra produksi cabai merah di Indonesia terdiri dari Provinsi Jawa Barat, Sumatera Utara, Jawa Tengah, Jawa Timur, Sumatera Barat, Aceh, dan Bengkulu memiliki rata-rata total produksi cabai merah mulai Tahun 2011 sampai 2015 sebesar 789,446 ton dari rata-rata total produksi di Indonesia sebesar 995,166 ton atau dengan konstribusi sebesar 79,33\%. Rata-rata produksi cabai merah Provinsi Jawa Barat sebesar 228.368 ton, Sumatera Utara sebesar 178,559 ton, Jawa Tengah sebesar 146,100 ton, Jawa Timur sebesar 95,439 ton, Sumatera Barat sebesar 58,064 ton, Aceh sebesar 45,390 ton dan Bengkulu sebesar 37,525 ton (Pusat Data dan Informasi Pertanian, 2016). Cabai merah terdiri dari cabai merah keriting dan cabai merah besar.

Varietas Unpad CK5 merupakan varietas cabai keriting yang baru dihasilkan oleh Laboratorium Pemuliaan Tanaman dan Teknologi Benih Fakultas Pertanian UNPAD yang memiliki gen ketahanan terhadap penyakit Anthraknos yang disebabkan jamur Colletitrichum dengan penampilan paling tahan dibandingkan varietas lainnya, oleh karena itu masih perlu dilakukan penelitian untuk menentukan pemupukannya yang optimum baik pupuk anorganik, organik maupun pupuk hayati. Salah satu jenis pupuk hayati yang sudah banyak di pasaran diantaranya Bion-Up (Kalay dkk., 2015; Setiawati dkk., 2017; Suwandi dkk., 2017).

Hasil penelitian Kalay dkk. (2015) menunjukkan penggunaan pupuk hayati secara signifikan meningkatkan pertumbuhan dan hasil tanaman Sawi (Brassica juncea L.), hasil penelitian Setiawati dkk. (2017) secara signifikan meningkatkan hasil kedelai edamame (Glycine max L.), dan hasil penelitian Suwandi dkk. (2017) secara signifikan efektif meningkatkan pertumbuhan dan hasil bawang merah. Kandungan pupuk hayati diantaranya adalah: 1) konsorsium mikroba yang sudah teruji menguntungkan, 2) mikroba yang dapat mendukung pertumbuhan tanaman karena memproduksi fitohormon seperti, sitokinin, auksin dan giberelin, 3) mikroba yang membantu dalam proses agregasi tanah karena menghasilkan eksopolisakarida (Setiawati dkk., 2017)

Menurut Kalay (2016) pupuk hayati berperan dalam meningkatkan ketersediaan unsur hara makro esensial ( $\mathrm{N}, \mathrm{P}$ dan $\mathrm{K})$ menghasilkan fitohormon yang dapat menstimulasi pertumbuhan tanaman, mampu mengurangi pemakaian pupuk NPK hingga 30\% dan dapat meningkatkan kuantitas dan kualitas hasil tanaman hortikultura. Hasil percobaan Puspadewi dkk. (2016) menunjukkan bahwa konsentrasi pupuk organik cair dengan dosis pupuk $\mathrm{N}, \mathrm{P}, \mathrm{K}$ berpengaruh terhadap pertumbuhan, komponen hasil, hasil tanaman, indeks panen dan total padatan terlarut jagung manis.

Berdasarkan latar belakang ini, maka perlu dilakukan penelitian penggunaan pupuk NPK dan pupuk hayati dalam meningkatkan pertumbuhan dan hasil cabai keriting CK5, dengan harapan penggunaan pupuk hayati bisa mengurangi penggunaan pupuk anorganik. Tujuan penelitian ini adalah untuk mengetahui pengaruh perlakuan dosis dosis pupuk NPK dan pupuk hayati terhadap pertumbuhan dan hasil tanaman cabai keriting CK5.

\section{Bahan dan Metode}

Percobaan dilakukan di Desa Sindanglaya, Kelurahan Cibeureum, Kecamatan Sukamantri, Kabupaten Ciamis Provinsi Jawa Barat. Waktu pelaksanaan percobaan berlangsung dari Agustus tahun 2017 sampai dengan Januari tahun 2018. Bahan-bahan yang digunakan dalam penelitian ini meliputi benih tanaman cabai keriting CK5, pupuk NPK (16:16:16), pupuk hayati , aquades, tanah, kompos, pupuk kandang, tray, polibag, dan pestisida. Alat-alat yang digunakan meliputi timbangan digital, alat tulis, alat dokumentasi (kamera), termometer, higrometer, ember, cangkul, gelas ukur, beacker glass, dan mulsa plastik.

Percobaan menggunakan Rancangan Split plot. Petak utama (main plot) adalah dosis pupuk NPK yang terdiri dari dua taraf perlakuan yaitu : $50 \%\left(\mathrm{a}_{1}\right)$ dan $100 \%$ NPK $\left(\mathrm{a}_{2}\right)$, dan anak petak (sub plot) adalah konsentrasi pupuk hayati yang terdiri dari tiga taraf perlakuan yaitu : $0 \%\left(b_{1}\right)$ ; $0,5 \%\left(b_{2}\right)$; dan $1 \%\left(b_{3}\right)$ Setiap perlakuan diulang empat kali. Parameter pertumbuhan dan hasil tanaman yang diamati adalah tinggi tanaman, diameter tajuk, panjang buah, dan bobot buah per tanaman.Data dianalisis menggunakan uji $F$ dilanjutkan dengan uji jarak berganda Duncan pada taraf $5 \%$.

\section{Hasil dan Pembahasan}

Pertumbuhan Tanaman Cabai Keriting CK5. Hasil analisis statistik menunjukkan bahwa 
pada 28 hari setelah tanaman (HST) terdapat pengaruh interaksi dosis pupuk NPK dan pupuk hayati terhadap tinggi tanaman cabai keriting (Tabel 1).

Tabel 1. Pengaruh dosis NPK dan pupuk hayati terhadap tinggi tanaman $(\mathrm{cm})$

\begin{tabular}{ccccc}
\hline \multirow{2}{*}{ perlakuan } & \multicolumn{4}{c}{ Dosis pupuk hayati } \\
\cline { 3 - 5 } & & $0 \%\left(\mathrm{~b}_{0}\right)$ & $0,5 \%\left(\mathrm{~b}_{1}\right)$ & $1 \%\left(\mathrm{~b}_{2}\right)$ \\
\hline \multirow{2}{*}{ Dosis } & $50 \%$ & $18,525 \mathrm{~A}$ & $18,300 \mathrm{~A}$ & $22,775 \mathrm{~B}$ \\
pupuk & $\left(\mathrm{a}_{1}\right)$ & $\mathrm{a}$ & $\mathrm{a}$ & $\mathrm{a}$ \\
NPK & $100 \%$ & $20,550 \mathrm{~A}$ & $24,650 \mathrm{~B}$ & $19,400 \mathrm{~A}$ \\
& $\left(\mathrm{a}_{2}\right)$ & $\mathrm{a}$ & $\mathrm{b}$ & $\mathrm{a}$ \\
\hline
\end{tabular}

Keterangan : angka yang diikuti dengan huruf kecil yang sama pada baris yang sama, huruf besar pada kolom yang sama tidak berbeda nyata menurut uji jarak berganda Duncan pada taraf 5\%.

Tabel 1 memperlihatkan bahwa tinggi tanaman cabai keriting pada 28 HST untuk dosis pupuk hayati $0 \%\left(\mathrm{~b}_{0}\right)$ tinggi tanaman yang diberi dosis pupuk NPK $50 \% \quad\left(a_{1}\right)$ tidak berbeda dibandingkan dengan dosis pupuk NPK $100 \%$ $\left(\mathrm{a}_{2}\right)$, untuk dosis pupuk hayati $0,5 \%\left(\mathrm{~b}_{1}\right)$ tinggi tanaman yang diberi dosis pupuk NPK 100\% $\left(\mathrm{a}_{2}\right)$ lebih tinggi dibandingkan dengan dosis pupuk NPK $50 \%\left(a_{1}\right)$, sedangkan untuk dosis pupuk hayati $1 \%\left(b_{2}\right)$ tinggi tanaman yang diberi dosis pupuk NPK $50 \%$ ( $\left.i_{1}\right)$ tidak lebih tinggi dibandingkan dengan dosis pupuk NPK 100\% $\left(\mathrm{a}_{2}\right)$. Dari data tersebut dapat dilihat bahwa pemberian pupuk hayati $1 \%$ dapat menurunkan penggunaan pupuk NPK menjadi $50 \%$. Tinggi tanaman terbaik dihasilkan oleh pemberian pupuk NPK $100 \%$ ditambah pupuk hayati $0,5 \%$.

Pada perlakuan $100 \%$ NPK, kebutuhan hara makro $\mathrm{N}, \mathrm{P}$ dan $\mathrm{K}$ terpenuhi. Nitrogen dibutuhkan untuk membentuk senyawa penting asam nukleat, enzim, protein serta klorofil, terutama untuk pertumbuhan vegetatif tanaman .Fosfor berperan dalam pembelahan sel, pembentukan asam nukleat,serta menyimpan dan memindahkan ATP dan ADP dalam pembentukan sel dan membantu proses asimilasi dan respirasi. Kalium berperan dalam bentukan pati, pengaktifan enzim, membantu proses fisiologis dan matabolik dalam sel, mempertinggi daya tahan terhadap kekeringan dan penyakit. Jika, unsur nitrogen dan fosfor tersedia rendah tanaman akan tumbuh lambat dan menjadi kerdil (Hardjowigeno, 1995)

Hasil penelitian Kalay dkk. (2016) menunjukkan bahwa pupuk hayati berperan dalam meningkatkan ketersediaan unsur hara makro esensial (N, P dan $\mathrm{K})$ menghasilkan fitohormon yang dapat menstimulasi pertumbuhan tanaman, mampu mengurangi pemakaian pupuk NPK hingga 30\% dan dapat meningkatkan kuantitas dan kualitas hasil tanaman hortikultura. Karamina dan Fikrinda (2016) menunjukkan bahwa pupuk organik cair yang mengandung mikroorganisme streptomycetes dengan dosis $25 \mathrm{ml} . \mathrm{L}^{-1}$ mampu meningkatkan pertumbuhan tinggi tanaman, jumlah daun, jumlah batang, dan bobot total tanaman kentang.

Hasil analisis statistik menunjukkan tidak terdapat pengaruh dosis pupuk NPK dan pupuk hayati baik secara mandiri maupun secara interaksi terhadap tinggi tanaman cabai keriting CK 5 pada umur 56 HST(Tabel 2), hal tersebut disebabkan tanaman sudah memasuki fase generatif, sehingga fotosintat yang dihasilkan lebih banyak untuk pembentukan buah seperti terlihat pada Tabel 3.

Tabel 2. Pengaruh dosis NPK dan pupuk hayati terhadap tinggi tanaman dan diameter tajuk pada 56 HST

\begin{tabular}{lcc}
\hline \multirow{2}{*}{ Perlakuan } & $\begin{array}{c}\text { Tinggi } \\
\text { Tanaman }(\mathbf{c m})\end{array}$ & $\begin{array}{c}\text { Diameter Tajuk } \\
(\mathbf{c m})\end{array}$ \\
\cline { 2 - 3 } & 56 HST & 56 HST \\
\hline NPK & & \\
$50 \%\left(\mathrm{a}_{1}\right)$ & $57,183 \mathrm{a}$ & $47,939 \mathrm{a}$ \\
100\% ( $\left.\mathrm{a}_{2}\right)$ & $61,558 \mathrm{a}$ & $46,420 \mathrm{a}$ \\
Pupuk Hayati & & \\
0\% ( $\left.\mathrm{b}_{0}\right)$ & $57,463 \mathrm{a}$ & $45,363 \mathrm{a}$ \\
$0,5 \%\left(\mathrm{~b}_{1}\right)$ & $60,825 \mathrm{a}$ & $44,269 \mathrm{a}$ \\
$1 \%\left(\mathrm{~b}_{2}\right)$ & $59,825 \mathrm{a}$ & $51,908 \mathrm{a}$ \\
\hline
\end{tabular}

Keterangan: angka yang diikuti dengan huruf kecil yang sama pada kolom yang sama adalah tidak berbeda nyata menurut uji jarak berganda Duncan pada taraf $5 \%$.

Hasil ini sejalan dengan hasil penelitian yang dilakukan oleh Wardhani dkk. (2014) dan hasil penelitian yang dilakukan Wahyuningratri dkk. (2017) menunjukkan bahwa pemberian pupuk hayati tidak berpengaruh terhadap tinggi tanaman cabai.

Diameter tajuk tanaman umur 56 HST tidak dipengaruhi oleh baik interaksi maupun pengaruh mandiri dari dosis NPK dan konsentrasi pupuk hayati (Tabel 2). Hasil penelitian Kelpitna (2009) juga menunjukkan bahwa diameter tajuk tanaman cabai tidak memperlihatkan perbedaan yang berarti diakibatkan oleh perbedaan pemberian pupuk hayati dan yang tidak diberikan pupuk hayati. 
Dari Tabel 3 dapat dilihat bahwa meskipun secara statistik dosis pupuk hayati tidak berpengaruh terhadap diameter tajuk, tetapi pemberian $1 \%$ pupuk hayati berpotensi untuk dapat meningkatkan diameter tajuk. Hasil percobaan Anjarsari dkk. (2015) pemberian asam humat dan pupuk hayati konsorsium (PHK) berpengaruh terhadap pertumbuhan tanaman teh belum menghasilkan klon GMB 7, nilai laju asimilasi bersih, luas daun, nisbah luas daun yang cenderung lebih tinggi dihasilkan oleh kombinasi 1,0 g PHK/ tanaman $+10 \mathrm{~mL}$ Asam humat dibandingkan perlakuan lainnya. Hasil penelitian Jamilah dkk. (2018) juga menunjukkan bahwa pengaruh konsentrasi yang berbeda dari pupuk hayati terhadap tanaman cabai tidak berpengaruh nyata terhadap tinggi tanaman, akan tetapi nyata terhadap jumlah cabang dan diameter tajuk tanaman.

Hasil Tanaman Cabai Keriting. Tabel 3 menunjukkan bahwa jumlah buah dan bobot buah cabai keriting CK 5 tidak dipengaruh oleh interaksi dosis pupuk NPK dan pupuk hayati, tetapi dipengaruhi oleh dosis pupuk NPK dan konsentrasi pupuk hayati secara mandiri. Hasil ini sejalan dengan penelitian Hapsoh dkk. (2017) yang menunjukkan bahwa aplikasi pupuk NPK berpengaruh terhadap panjang buah dan lebih menyebabkan peningkatan hasil tanaman cabai rawit dibanding penambahan kompos.

Tabel 3. Pengaruh dosis NPK dan konsentrasi pupuk hayati terhadap jumlah buah dan bobot buah per tanaman

\begin{tabular}{lcc}
\hline Perlakuan & $\begin{array}{l}\text { Jumlah } \\
\text { buah }\end{array}$ & $\begin{array}{l}\text { Bobot buah } \\
\text { (g) }\end{array}$ \\
\hline NPK ( A ) & & \\
$50 \%\left(\mathrm{a}_{1}\right)$ & $85,917 \mathrm{a}$ & $776,51 \mathrm{a}$ \\
$100 \%\left(\mathrm{a}_{2}\right)$ & $102,833 \mathrm{~b}$ & $940,65 \mathrm{~b}$ \\
Pupuk Hayati ( B ) & & \\
$0 \%\left(\mathrm{~b}_{0}\right)$ & $90,375 \mathrm{a}$ & $820,71 \mathrm{a}$ \\
$0,5 \%\left(\mathrm{~b}_{1}\right)$ & $93,625 \mathrm{ab}$ & $865,06 \mathrm{ab}$ \\
$1 \%\left(\mathrm{~b}_{2}\right)$ & $99,125 \mathrm{~b}$ & $889,98 \mathrm{~b}$ \\
\hline Keterangan: angka yang diikuti dengan huruf kecil \\
yang sama pada kolom yang sama adalah tidak \\
berbeda nyata menurut uji jarak berganda Duncan \\
pada taraf 5\%.
\end{tabular}

Jumlah dan bobot buah dipengaruhi oleh dosis NPK, jumlah dan bobot buah yang diberi $100 \%$ dosis NPK lebih banyak dibandingkan dengan yang diberi 50\% NPK. Aplikasi pupuk anorganik NPK berperan untuk mencukupi kebutuhan hara tanaman cabai dalam pembentukan buah terutama unsur hara $\mathrm{N}, \mathrm{P}$, dan K. Pemberian N, P, dan K pada tanaman dapat mempercepat pembungaan, perkembangan biji dan buah, membantu pembentukan karbohidrat, protein, lemak dan berbagai persenyawaan lainya (Hardjowigeno, 1995).

Menurut Prasetya (2014) penggunaan pupuk majemuk NPK menjadikan tanaman cabai banyak mengandung klorofilsehingga lebih hijau dan segar, batang menjadi kuat dan tegak, dapat mengurangi resiko rebah menambah daya tahan tanaman terhadap gangguan hama, penyakit, dan kekeringan, , memacu pertumbuhan akar dan sistem perakaran yang baik, memacu pembentukan bunga, memperbesar ukuran buah, umbi, dan biji-bijian mempercepat panen dan menambah kandungan protein, mengurangi resiko kerusakan selama pengangkutan dan penyimpanan, memperlancar proses pembentukan gula dan pati

Aplikasi pupuk hayati dengan konsentrasi $1 \%$ dapat meningkatkan jumlah dan bobot buah cabe keriting CK 5 dibandingkan dengan tanpa pupuk hayati tetapi tidak berbeda dengan yang diberi $0,5 \%$ pupuk hayati, sehingga konentrasi yang efektif adalah 0,5\% karena peningkatan konsentrasi pupuk hayati menjadi $1 \%$ tidak meningatkan hasil. Hasil penelitian yang serupa dilaporkan Addieny (2011) bahwa pupuk organik yang diperkaya mikrob aktivator nyata meningkatkan hasil pada tanaman cabai. Keberadaan mikroba yang berfungsi sebagai pupuk hayati sangat penting untuk ketersediaan dan kelarutan hara yang dibutuhkan tanaman untuk pertumbuhan dan peningkatan hasil (Gentili dan Jumpponen, 2005).

Mikroorganisme yang terdapat pada pupuk hayati yang digunakan adalah Azotobacter chroococcum, Azotobacter vinelandii, Azosprilium sp., Acinetobacter sp., Pseudomonas capacia, dan Penecillium sp. Bakteri dari famili Azotobacteraceae ini merupakan sebagian besar dari bakteri pemfiksasi nitrogen yang hidup bebas.. Azotobacter dapat menghambat pertumbuhan jamur yang sangat patogen seperti Alternaria dan Fusarium. Azotobacter dapat meningkatkan tingkat perkecambahan biji, pertumbuhan tanaman, tegakan tanaman, dan pertumbuhan vegetatif. Bakteri ini juga menghasilkan senyawa eksopolisakarida (EPS) dan asam lemak, yang mampu memperbaiki perkembangan akar karena menghasilkan 
fitohormon golongan auxindansitokinin (Suryatmana, dkk., 2008). Azospirillum dapat menghasilkan fitohormon, fiksasi nitrogen, produksi nitrit, dan peningkatan penyerapan mineral oleh tanaman secara (Holguin, et al., 1999). Pseudomonas cepacia dapat memicu pertumbuhan tanaman (Plant Growth Promoting Rhizobacteria/PGPB) (Coenye dan Vandamme, 2003). Menurut Rao (1994) Pseudomonas mempunyai kemampuan melepas $\mathrm{P}$ dari ikatan $\mathrm{Fe}$, Al, Ca dan $\mathrm{Mg}$ sehingga $\mathrm{P}$ yang tidak tersedia menjadi tersedia bagi tanaman, Penicillium sp dapat berperan sebagai stimulan pertumbuhan tanaman (Phuwiwat dan Soytong, 2001). Spesies bakteri Acinetobacter sp. diketahui mampu menghasilkan enzim ACC (1aminocyclopropana-1-carboxylate)-deaminase yang dapat mengurangi produksi etilen dalam jaringan tanaman. Acinetobacter juga dapat meningkatkan kandungan klorofil pada tanaman monokotil dan dikotil dalam sistem budidaya hidroponik (Suzuki, et al., 2014)

\section{Kesimpulan}

Berdasarkan hasil percobaan maka dapat disimpulkan bahwa :

1. Pengaruh interaksi dosis NPK dengan konsentrasi pupuk hayati hanya terjadi pada tinggi tanaman umur $28 \mathrm{HS}$, perlakuan yang terbaik adalah dosis NPK 100\% dengan konsentrasi pupuk hayati 0,5\%.

2. Pupuk NPK dan konsentrasi pupuk hayati secara mandiri berpengaruh terhadap jumlah dan bobot buah. Dosis NPK yang terbaik adalah $100 \%$ NPK, konsentrasi pupuk hayati yang terbaik adalah $0,5 \%$.

\section{Daftar Pustaka}

Addieny, L. . 2011. Efektivitas Penggunaan Pupuk Organik yang Diperkaaya Mikrob Aktivator dalam Mengatur Keseimbangan Tajuk dan Akar Tanaman Cabai (Capsicum annuum L.). Skripsi. IPB. Bogor

Anjarsari, I.R.D. · S. Rosniawaty - C. Suherman. 2015. Rekayasa ekofisiologis tanaman teh belum menghasilkan klon GMB 7 melalui pemberian asam humat dan pupuk hayati konsorsium. Jurnal Kultivasi Vol. 14(1) Maret 2015.
Coenye, T and P. Vandamme. 2003. Minireview : Diversity and significance of Burkholderia species occupying diverse ecological niches. Environmental Microbiology (2003) 5(9), 719-729

Hardjowigeno, S. 1995. Imu Tanah. Akademika Pressindo, Jakarta.

Holguin, G., C. L. Patten, and B. R. Glick. 1999. Genetics and Molecular Biology of Azospirillum. Q Springer-Verlag, Biol Fertil Soils 29, pp. 10-23.

Gentili, F., and A. Jumpponen, 2005. Handbook of Microbial Fertilizers. Rai MK, editor. New York (US): The Hawort Press, Inc.

Hapsoh, Gusmawartati, A. I. Amri, dan A. Diansyah. 2016. Pengaruh Pemberian Pupuk NPK DGW Compaction dan POC Ratu Biogen terhadap Pertumbuhan dan Hasil Tanaman Cabe Rawit (Capsicum frutescent L.) Hibrida F-1 Varietas Bhaskara. Jurnal AGRIFOR Vol. XV No. 1, Maret 2016, hal. 15-23.

Jamilah, N., H., Zahanis, dan Ernita, M. 2018. Penetapan Konsentrasi Pupuk Organik Cair Unitas Super yang Tepat pada Tanaman Cabai Rawit Lokal (Capsicum frutescens L.). EnviroScienteae, Vol. 14 No. 1, April 2018, hal. 33-37.

Kalay, A. M., R. Hindersah, A.Talahaturuson, M. R. Uluputty, dan A.F. Langoi. 2015. Pertumbuhan dan Hasil Tanaman Sawi (Brassica juncea L.) setelah Aplikasi Pupuk Hayati Tunggal dan Konsorsium. Agrologia, Vol. 4 No.1, April 2015, hal. 1520.

Kalay, A. M., R. Hindersah, A. Talahaturuson, dan A.F. Langoi. 2016. Efek Pemberian Pupuk Hayati Konsorsium terhadap Pertum buhan dan Hasil Tanaman Sawi (Brassica juncea L.). Jur.Agroekotek 8 (2) : 131 - 138, Desember 2016.

Karamina, H. dan W. Fikrinda. 2016. Aplikasi pupuk organik cair pada tanaman kentang varietas granola di dataran medium. Kultivasi Vol. 15(3) Desember 2016.

Kelpitna, A. E. 2009. Cara Aplikasi Pupuk Daun pada Tanaman Cabal Merah (Capsicum annuum L.). Buletin Teknik Pertanian, Vol. 14 No. 1, hal. 37-39.

Phuwiwat, W., and Soy-tong, K. 2001. The Effect of Penicillium notatum on Plant Growth. Fungal Diversity 8: 143-148. 
Pusat Data dan Sistem Informasi Pertanian. 2016. Outlook Cabai, Komoditas Pertanian Sub Sektor Hortikultura: Cabai Merah. Jakarta:, Sekretariat Jenderal Kementerian Pertanian.

Prasetya, M.E. 2014. Pengaruh Pupuk NPK Mutiara dan Pupuk Kandang Sapi Terhadap Pertumbuhan dan Hasil Tanaman Cabai Merah Keriting Varietas Arimbi. Jurnal AGRIFOR, Vol. XIII No. 2, Oktober 2014, hal. 191-198.

Puspadewi, S., W. Sutari, dan - Kusumiyati. 2016. Pengaruh konsentrasi pupuk organik cair (POC) dan dosis pupuk N, P, $\mathrm{K}$ terhadap pertumbuhan dan hasil tanaman jagung manis (Zea mays L. var Rugosa Bonaf) kultivar Talenta. Kultivasi Vol. 15(3) Desember 2016.

Rao, Subba. 1994. Mikroorganisme Tanah dan Pertumbuhan Tanaman. Diterjemah-kan oleh Herawati Susilo. Jakarta: UI Press.

Setiawati, Mieke Rochimi, Emma Trinurani Sofyan, Anne Nurbaity, Pujawati Suryatmana, dan Gordon Pius Marihot, 2017. Pengaruh Aplikasi Pupuk Hayati, Vermikompos dan Pupuk Anorganik terhadap Kandungan N, Populasi Azotobacter sp. dan Hasil Kedelai Edamame (Glycine max L.) Merill pada Inceptisols Jatinangor. Agrologia, Vol. 6, No.1, April 2017, Hal. 1-10.
Suryatmana, P., R. Hindersah dan A. Yusuf. 2008. Pemanfaatan Molase sebagai bahan baku mediaproduksi Azotobacter. LPP Unpad.

Suwandi, Gina Aliya Sopha, Liferdi Lukman, dan Muhammad Prama Yufdy, 2017. Efektivitas Pupuk Hayati Unggulan Nasional terhadap Pertumbuhan dan Hasil Bawang Merah. J. Hort. Vol. 27 No. 1, Juni 2017 : 23-34.

Suzuki, W., Sugawara, M., Miwa, K and M. Morikawa. 2014. Plant growthpromoting bacterium Acinetobacter calcoaceticus P23 increases the chlorophyll content of the monocot Lemna minor (duckweed) and the dicot Lactuca sativa (lettuce).J Biosci Bioeng.118 (1):41-44

Wahyuningratri, A., Aini, N., dan Heddy, S., 2017. Pengaruh Konsentrasi dan Frekuensi Pemberian Pupuk Hayati terhadap Pertumbuhan dan Hasil Cabai Besar (Capsicum annuum L.). Jurnal Produksi Tanaman. Vol. 5 No. 1, Januari 2017, Phal. 84-91.

Wardhani, S., Purwani, K. I., dan Anugerahani, W. 2014. Pengaruh Aplikasi Pupuk Hayati Terhadap Pertumbuhan dan Produktivitas Tanaman Cabai Rawit (Capsicum frutescens L.) Varietas Bhaskara di PT Petrokimia Gresik. Jurnal Sains dan Seni Pomits, Vol. 2 No.1, hal. 1-5. 